\title{
Animal welfare: A human right?
}

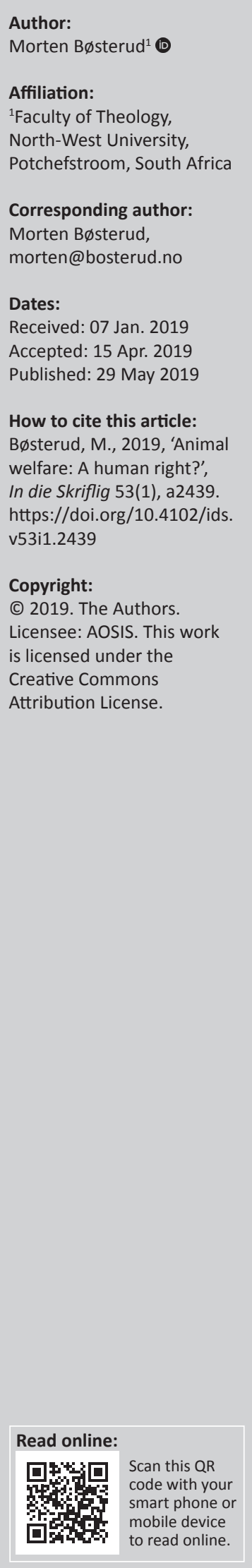

The modern-day Western consumers will need to accept purchasing their foodstuffs from the typically chain organised supermarkets relying on the main supply chains of food, which are produced within the mass production paradigm of contemporary agriculture. There will be some exceptions from this main rule, but for the contemporary Western citizen, these exceptions will not suffice to secure subsistence on a standalone basis. To an increasing number of Western consumers, animal welfare aspects connected to modern farming practices are concerning, and increasingly being viewed as systematic mistreatment of animals. For those adhering to a Christian morality, the question arises as to whether consuming animalbased food produced under the modern agricultural paradigm may be in violation of their scripturally based stewardship obligations under the covenant with God in creation. Further, if in violation of their moral obligations, the question becomes whether the acceptance of modern animal husbandry practices as in reality, the sole source of animal-based foodstuffs for physical subsistence will also be a violation of the consumers' right to religious expression and observance as guaranteed under United Nations (UN)'s Universal Declaration of Human Rights. These questions are elaborated on in this article, and briefly contrasted against the observance of religiously oriented rules connected to foodstuffs under the Islamic and Judaic paradigms. A system for marking animal-based foodstuffs according to Christian-ethical norm alignment is suggested.

Keywords: Stewarding obligation under creation; Animal welfare; Human rights; Animal-based food; Religious observance; Food marking.

\section{Introduction}

A substantial part of human endeavour relates to food production, and animals are part of this as sources of food, and still in parts of the world as beasts of burden. The scale of animal husbandry for food production is vast, and globally as many as 70 billion land animals are killed per year for use as human sustenance. By including the killing of wild and farmed fish, the total of daily killed animals for human consumption will exceed 3 billion (Faunalytics n.d.; Sentient Media n.d.). Thus, in the US alone more than 9 billion chickens are raised for meat and 305 million chickens are raised for eggs per year (Peta n.d.). Over the last few decades, public awareness of how animals are treated in society has become the focus of increased attention. There is concern how animals are treated and used in food production, scientific research, industrial products, marketing, clothing and related products, as well as in the entertainment industry. Different political and special interest groups have focused their attention toward the perceived betterment of animal conditions, hereunder their potential legal rights. The focus of justification for these initiatives seems to be based on moral grounds (Peta n.d.; Wise 2000). In this article the focus will not be on whether animals indeed are treated in an unethical manner in contemporary society, but whether or how we as humans can exist as unencumbered consumers and societal partakers within the current paradigm of treating animals and using them as contributors to our subsistence. This question will be observed from a Christian-ethical vantage point under the Reformed paradigm, and the focus will be on rights issues, hereunder potential animal rights concerning welfare and human rights to freely express religious belief. Thus, albeit I realise that many countries will have legislation describing how to treat animals under human husbandry, evaluating the quality of such rules will fall outside the scope of this article. Aspects of food production pertaining to pollution and other harmful practices such as fertilising and genetic modification of plants are also not treated here. The sole focus will be on how we treat animals in situations related to food production. Further, as the main focus in this article will be on modern large-scale animal husbandry, it is worth pointing out that in this article, any alternative manners of animal-based food production will not be presented, and indeed, the assumption here is that it will be possible to treat animals equally well or poorly in both large and small-scale production settings. For the purposes of this article, the term animal will be used to cover any 
living organism that may be part of the food production for human consumption, including all land and sea mammals, birds, fish, crustaceans, insects et cetera.

\section{Practical reality}

In modern-day farming practices, animal husbandry involves a high concentration of animals, yield-effective breeds, transportation and high efficiency feeding practices. From such husbandry, numerous new diseases have become increasingly problematic, and producers seek to counteract these by adding antibiotics and other medicine to the feed. Animal husbandry is then becoming a constant race between disease resistance and efficient product output (Gaggìa, Mattarelli \& Biavat 2010). What is less discussed than the general problems of disease, are that parts of the increasing disease challenges stemming from the practice of breeding evermore fast growing and meat efficient animal breeds. This again leads to the situation in which the natural immune system of the animals is less and less capable of tackling diseases. This will be counteracted by adding more medicine to the feed, in an ongoing escalating cycle. Other potentially harmful and sickness-inducing practices can involve unhealthy breeding and over-feeding, to the extent that certain animals, like poultry, no longer possess the natural ability to freely move around and carry their own body weight. They are being crippled by design and are prone to heart attacks and numerous other health problems (Mason \& Finelly 2006). Such circles of production, breeding practices and medication usage, may be regarded as a form of animal husbandry where the animals have no ability to survive through their own resources, but that we as humans are forcing them to stay alive for our own purposes.

In addition to the problems related to health under production, animals are increasingly being transported over longer distances to abattoirs for slaughtering, and this induces stress and disease in the animals, necessitating even more medication and artificial means of keeping them alive and in relative health (Ljungberg, Gebresenbet \& Aradom 2007). It is possible to give numerous examples of modern farming practices, and how these may induce added or unnecessary pain and suffering to the production of animals. However, for the purposes of this article, the few examples mentioned should suffice to illuminate the problems that are connected to the production of animal products and subsequent consumption.

In addition to the actual food production, animals are frequently being used in research and product testing as subjects of live experimentation, sometimes as part of developing new breeds or qualities in extant breeds of animals for further use in food production. A central matter to identify in connection with the research use of animals connected to food production or otherwise, is to assess whether the practice is painful and whether this pain is necessary. Examples of unnecessary experimentation could be those used for educational purposes when the experiments have been performed previously and the outcome is well known. In addition, some research projects may in themselves prove to be superfluous, as the result may be obvious, and thus the inflicted pain is unnecessary (Ryder 2006). For the purposes here, such experimentation will be of interest in so far as the tests are for purposes of producing animal-based food products.

When animals are used in marketing and entertainment, such as circuses, children's parties, hunting et cetera, the matter of respecting the animals and their dignity also may raise concern in wide societal circles. This topic, however, falls, outside the scope of this article, where the focus is on the physical treatment of animals (Peta n.d.).

It is practically impossible for the modern consumers and wage earners to produce their own food. Thus, the consumers will need to consume what is readily available in the supermarkets and they are not left with any real choice. The emergence of the vegan movement may be rooted in public sentiment that animals are not treated in a humane manner. To escape participating in this, the only current viable way out for the ordinary consumer may therefore be to turn away from all use of animal products.

\section{Ethical perspectives Secular movements}

Humans' interaction with animals has traditionally been in the context of hunting, farming or leisure, and the modern aspects of industrial farming and research laboratories have not been areas of much ethical concern. In recent decades the question of how we treat animals, and indeed whether animals have any rights has become an area of societal contention that needs to be explored through an ethical lens.

For the utilitarian Jeremy Bentham (1748-1832), the ethos was that the good human acts were those that increased happiness. To him, happiness was not merely confined to humans; animals were equally recognised as being able to experience happiness and pain. Already in Bentham's time, the topic of animals and their cognitive faculties was being discussed, and to some it was of importance whether animals could think or not, in order to decide whether at all it is needed to consider how to treat them. For Bentham (1907), however, the question was not 'Can they reason? nor, Can they talk? but, Can they suffer?' An important clarification that will shed further light on the matter is made by Regan (1987), who explains that animals may be subjected to suffering both by being actively inflicted with harm, and by being deprived of necessary means to fulfil physical needs and satisfaction.

In contemporary philosophical discourse, Singer (1995) has become a prominent proponent of promoting animal welfare. To him it would be pertinent to award rights to animals akin with human rights. He builds his arguments mainly on the animals' capacity for feeling pain and suffering and utilises examples from research and factory farming to draw 
sympathy to his philosophical stance. His argumentation fails on some points, as he is an avid vegetarian, and seems to ignore the principle that if someone has rights, others need have corresponding obligations to honour them. Such obligations would then rest with humans, and the point to argue should rather be what obligations humans have towards animals and their suffering, and from where such obligations may be drawn. For a utilitarian thinker like Singer, the problem is that there is no higher authority from which to instil obligations in humans, so his focus needs to stay solely with the rights side of the discourse. Waldau (2006) on the other hand, examines the connection between religion and concern for animals. His outlook is more positive, as he recognises that several world religions acknowledge the plight of some animals, and that it is a human responsibility to care for nature, including our fellow beings, animals.

\section{Christian thought}

The obligation perspective described above will be the most practical entry into animal rights issues, and Scripture renders guidance in several passages. In Genesis 1:26-27 we learn that humans alone were created in 'the image of God' and this is generally understood in an exclusive sense, only pertaining to humanity. That animals are not created in God's image does not negate our obligations towards them. Regarding the human obligation towards animals, we learn in Genesis 1:28 that we should 'fill the earth and subdue it. Rule over the fish in the sea and the birds in the sky and over every living creature that moves on the ground'. The use of the words 'subdue' and 'rule' can indicate the human duty of dominion over nature (Geisler 2010). However, even as humans are given to rule over other creatures, in Psalm 24:1 we are reminded that 'the earth is the LORD's, and everything in it, the world, and all who live in it'. This indicates the stewardship obligation over nature that rests with humanity (Kearns 1996). Although the above stance is a widely adhered to theological position among mainstream Christians, there are those who advocate that Christian religious observance involve vegetarianism, and that this may be founded in Scripture. The claim is that veganism is founded in Scripture, as purely plant-based food was the sole sustenance that was available in Eden, humanity's original dwelling place and home, and which was directed as food for humans in Genesis 1:29:

Then God said, 'I give you every seed-bearing plant on the face of the whole earth and every tree that has fruit with seed in it. They will be yours for food.'

The idea is that eating animal-based food represents a postFall situation for humanity (Gn 9:3), and thus is not the pure Edenic diet that was originally meant for humans to enjoy (Calvert 2008; Wirzba 2019). Such a strict veganism position is not followed by all proponents of Christian vegetarianism, as there are voices in the theological discourse who argue that we do not know from scriptural sources whether Jesus ate meat, but that there are indications that he may have consumed fish (Horrell 2008). Such indications may be drawn from the passages where Jesus feeds the multitudes (e.g. Mt 14:13-21; Mk 6:31-44), and the miraculous catch (Jn 21:6; Lk 5:4-7). Even though these passages do not explicitly describe Jesus as eating fish, it will be prudent to interpret that he did not oppose the eating of fish, and further, from Mark 7:19, we understand that Jesus did not approve of any food laws or rituals, like those found in the old law of the Jews. That the question of how and what to eat was a matter of contention among early Christians, becomes evident when reading Romans 14, where verse 3 reads:

The one who eats everything must not treat with contempt the one who does not, and the one who does not eat everything must not judge the one who does, for God has accepted them.

and Romans 14:7 states 'Whoever eats meat does so to the Lord, for they give thanks to God; and whoever abstains does so to the Lord and gives thanks to God'. When viewed in connection, the above referred scriptural passages from both Old and New Testament will give support to the position that for Christians, it is acceptable to consume food from both plant and animal sources, and this will be the assumption in this article. Veganism or vegetarianism in its different forms will then not be regarded as a Christian norm under the Reformed paradigm, but rather as a lifestyle choice open for Christians to make if they so wish. It should also be pointed out, that only strict veganism would leave the practitioners outside the scope of this article, as vegetarianism that involves eating fish, cheese, honey or eggs, for example would fall inside the scope, as such vegetarian practice would still rely on animal husbandry.

In a Reformed Christian-ethical philosophy, Geisler (2013) explains that there is no place for the concept of animal rights, but maintains that we need to care for nature, as it belongs to God (Ps 24:1), and our job is to care for it, including its creatures. In my view, this is a viable position, and to focus on the human obligation rather than the rights of other creatures, places responsibility where it is due. We have seen that Singer's theories are tainted with the lack of higher authority to care for nature. Thus, he focuses on awarding rights, but this problem is solved within the realm of Scripture through the human obligation toward nature as God's caretakers. Animals have no other way to protect themselves than through the stewardship obligation of humans, and through these obligations, animals will not need to be subjected to imposed artificial rights. Bentham's focus on the capacity to suffer, and the corresponding human obligation not to inflict pain, would be a pertinent guide for Reformed Christian ethics as a norm. A natural conclusion for the Christian would be that the obligation is to care for animals and not to inflict suffering on them, and not to deprive them of their basic, natural needs. The focus on human obligations towards animals based on scriptural instruction is increasing. Within practically oriented theological communities there is a budding awareness of how human obligations under creation may be grossly neglected by treatment of animals. This occurs both as part of food production and scientific and industrial testing, and this focus is represented inter alia by Bøsterud and Vorster (2017). 
As explained above, from a Christian-ethical perspective, the question is not whether animals can be regarded as having rights that humans need to observe, but how we as humans perform our stewardship responsibility in accordance with our covenant with God in creation (Gn 1:28). From a Christian perspective, the conclusion under the Reformed paradigm would be the following: to engage in practices that contribute to unnecessary infliction of pain in animals, or that deprive animals of basic natural needs, is immoral, whether connected to economic or scientific activity. The questions for the Christian ethically concerned consumer are the following: Is it our right as individuals to be able to practice the scripturally founded stewardship obligations towards animals that follows from our covenant with God in creation?, and How can contemporary animal husbandry and food production be brought into a state where we as consumers are not violating our scripturally given obligations, and this by our mere sustenance-based food consumption in a modern consumerist society?

\section{Human rights}

The topic of liberal freedoms and rights has been part of the Western philosophical, religious and secular discourse over centuries, and different starting points and perspectives are proposed, such as in the English Magna Carta of 1215. However, the Magna Carta did not in any way contain universalistic perspectives on the rights of humans, as it only represented a settlement between King John and the barons. In this settlement the landowning men were secured some rights to property and personal corporeal freedom, such as not being arrested or molested, or being bereft of their properties without a precedent due legal process. The same may be said of the English Bill of Rights of 1689, which was also concerned with the rights of parts of society only. Although it touched upon topics such as free speech, this freedom was not taken far, and, protestants (and not Catholics) were allowed to bear arms to their defence, et cetera (Clapham 2015).

During the Enlightenment era, other influences on the emerging ideas on general human rights were connected to the idea of 'natural rights'. After this cognition these rights existed with the individual, that in principle flowed from the state of being human. A proponent of such a line of thought was John Locke (1632-1704), who in his Second treatise of government of 1690 , perceived that in a so-called natural state, humans would enjoy a state of freedom, albeit they were not in a position of license (Locke 1823). In other words, rights then existed, although there was no way to enforce or enjoy them. Similar thoughts were held by Jean-Jacques Rousseau (1712-1778), who in his book, The social contract, theorises that humans in a societal setting had entered a form of a social contract, and that through this, their original natural liberty was lost. Rousseau thought that in return for giving up his natural liberty through the social contact, the citizen would in its stead gain a civil liberty, which originated in the contractual society (Rousseau 1968). This idea of the social contract was influential in the freedom movement of the
French Revolution of 1789, and had further reach beyond this, as other peoples around the world have attempted to express suitable relationships between the rulers and the ruled. A major flaw of this discourse, with the ideas of the emergent freedom movements of their time, such as the French and American declarations of rights, was that they only bestowed such freedoms to men, and excluded women. This was opposed to both in France by Olympe de Gouge (1748-1793) in her Declaration of the Rights of Woman of 1791, and in England by Mary Wollstonecraft (1759-1797) in her Vindication of the Rights of Woman of 1792, but unfortunately to no contemporaneous avail (Clapham 2015; De Gouge 1791; Wollstonecraft 1792).

A later thinker of the same era, Jeremy Bentham, argues against the idea of the existence of natural, innate rights belonging to or originating in the human being. To him, this was such a foreign and preposterous idea that he famously characterised it as 'nonsense upon stilts' (Bentham 1843: 501). To him, wanting something was not the same as having it. In other words, being thirsty is not the same as having water. Bentham, who was a lawyer by background, believed that the only real and reliable rights were legal rights, and it was the creators of the laws who were the generators of whatever rights humans were to enjoy. The idea that a government, as the law maker, was to be restricted by a concept of natural rights in its rule, would be to invite anarchy and instability, he believed (Bentham 1843). As the 19th century political and societal changes continued, Karl Marx (1818-1883) attains the view that individual rights were not beneficial qualities in a society, but he does not share Bentham's pragmatic justifications for this view, as for Marx, individuality was seen as a moral threat to the good of the collective. In other words, the individual interests were counteracting the good of society (Marx 1843).

The above brief description of the main philosophical schools of thought leading up to the establishment of a wider acceptance of the idea of universal human rights on a global scale, will illuminate some of the complexity involved on a moral and philosophical level. Despite the lack of completeness available in a format like here, the brief exploration should suffice as foundational for understanding the practical and political steps. The 20th century with is first half of near-global warfare, led the global powers to establish the United Nations (UN) as a means in securing peace, and with it, the Declaration of Human rights soon followed.

\section{United Nations human rights declaration}

At the beginning of the 20th century, there were certain sociopolitical currents in the Western world leading to the establishment of organisations whose purpose were to increase equality among people and not least, focusing on labour rights and adjacent dignity perspectives. Notable organisations to mention here, would be the League of Nations and the International Labour Organisation (ILO). It should, however, be emphasised that despite their valuable 
work for equality and anti-slavery, the rights that were in focus were to be derived from the states involved, and not to be the belonging of the individual citizen of the states (Clapham 2015). It was as a result of the Second World War that the international community increased its peaceful cooperation and the UN charter was signed on 26 June 1945, just as the war had finally ended. The UN charter presupposed a focus on increased individual human rights for the future, but as the war had just ended, the emphasis was on bringing war criminals to justice, and this spurred on the establishment of specialised single purpose law courts in the form of war crime tribunals arranged by the victorious states. These were most notably the Nuremberg International Military Tribunal and the Tokyo Tribunal, where some of the highest profile war criminals were tried for crimes against peace, war crimes and crimes against humanity. In Nuremberg 12 were sentenced to death and 5 to long prison sentences, and in Tokyo 7 were sentenced to death and 16 to life sentences (Clapham 2015; Robertson 2012). Considering the scale of the horrors of the Second World War, the numbers may not appear too impressive, and it is perhaps easy to appreciate the perceived need at the time for more comprehensive rules on rights, where it is not the state but the individual who 'owns' such rights.

With the tribunals concluded, the aim of the UN signatories could be directed to other matters than trying criminals, and the attention once again was given to the matter of human rights. The UN's precursory work leading up to the Universal Declaration of Human Rights (UN n.d.), the 'Declaration', consisted of draft work from 1946 to 1948, and on 10 December 1948, the Declaration was adopted by the UN General Assembly. When adopted, this was in its time perceived as a great victory for the cooperation of politically diverse and oftentimes conflicting regimes with different religious and philosophical traditions and systems, but unfortunately the resolution of the General Assembly was not legally binding. As such, the Declaration was merely of a programmatic character, and it left open a multitude of interpretations and possible modes of operationalisation. Due to that the Declaration was not binding on the signatories already in 1947; the UN Commission of Human Rights therefore initiated and proposed additions to the Declaration in the form of multilateral treaties on human rights. This resulted in two International Covenants on Human Rights, one covering economic, social and cultural rights, and one on civil and political rights. The covenants were adopted in 1966 and came into force in 1976 (Vorster 2004). A reason for this time consumption may have been that some Western states still had overseas colonies at the time, and thus were reluctant to introducing a universality to the rights, as that would then become the rights also of their colonial subjects (Robertson 2012).

Despite the apparent victory for civil rights and freedoms in that the UN has established the Declaration and the attendant covenants, there were also substantial criticisms directed against the rule set. One aspect that was brought to the fore is that the Declaration was perceived as ethnocentrically biased towards Western ideals, with typically Western or capitalist values such as the right to own property (art. 17), and the freedom not to belong to associations (art. 20). Another criticism was that the rules might appear relative, for example the right to just and favourable remuneration for work (art. 23), and the right to enjoy an adequate standard of living (art. 25), both examples of standards which may vary culturally. The criticism against ethnocentricity and relativity are therefore a criticism against the universality of the Declaration in practice; a value that may be regarded as a core tenet of the declaration and its basic ethos (Griffin 2008).

The Declaration is centred on the rights of the individual, and the signatory states are the ones who will be their guarantors. This strong role of the states may be perceived as unfortunate, as it will then be the order of the states to pass laws and regulations to secure such rights to the individual, and through this, the individual will be left to argue that the domestic laws are in violation of the covenants or the Declaration. In other words, the practicality of the human rights of the individual will this way appear removed, derived and distanced from the Declaration itself, and we as citizens may lose our sense of ownership and agency to the values of the Declaration (Beitz 2011). Despite this criticism, the way that the Declaration was formulated as universal, represents a substantial break with the pragmatic and collectivist ideas of Bentham and Marx. Despite the apparent Western ethnocentricity, it may evoke the individual centric Enlightenment ideas of Rousseau and Locke that are represented as core tenets of the Declaration.

The universal and individualist focus of the Declaration is apparent in several, if not all articles, and not least in the article which will be of special interest here, viz. article 18, which reads:

Everyone has the right to freedom of thought, conscience and religion; this right includes freedom to change his religion or belief, and freedom, either alone or in community with others and in public or private, to manifest his religion or belief in teaching, practice, worship and observance.

\section{Food consumption as religious observance}

Of the questions presented in the section on ethical perspectives above, it is the first question that will be illuminated by the Declaration's article 18: Is it our right as individuals to be able to practice the scripturally founded stewardship obligations towards animals that follows from our covenant with God in creation? The operative check against the wording of article 18 will then be whether our fulfilment of the scripturally based stewardship obligation towards creation will be covered by the explicitly expressed right 'to manifest his religion' and its 'observance' as part of life expression. From the face of it, this wording would lend strong support to the right of ethically motivated Christian 
individuals to include food consumption as part of their religious observance as dictated in the creation teachings in Genesis. The wording of article 18 is repeated and expanded somewhat in the International Covenant on Civil and Political Rights of 1966 (Covenant), where some further clarifications are given (OHCHR n.d.). Relevant wording for this article is found in the Covenant's article 18, subsection 3, which reads:

Freedom to manifest one's religion or beliefs may be subject only to such limitations as are prescribed by law and are necessary to protect public safety, order, health, or morals or the fundamental rights and freedoms of others.

As it appears from the quote, it connects directly to the main rule of article 18 and its focus of right to 'manifest one's religion'. From the express allowed limitations that follow, one understands that the bar shall be laid high if modifications in the rights of individuals to manifest their religion is to be allowed. From this follows that the starting point of article 18 , as supporting the rights in question here, will have been further bolstered by the referred section of the Covenant. From the context of the Declaration and Covenant wordings as quoted, it will be clear that it is the responsibility of the signatory states to allow for such unencumbered religious expression to be possible. Even though the wordings do not expressly state such a responsibility, it should be regarded as an omission on the part of a state if religious observance is made difficult, or otherwise impeded by practicalities in the civil society, such as connected to food production and attendant infrastructure. Connected to the rights as secured in the wordings, it must clearly be the spirit of the stipulations that should rule over their strict literal interpretations.

If we consider the practical realities of modern life and how we are to consume the food that is available to us, it would be difficult to understand how Christians today may be able to observe their stewardship obligations under the creation, short only of perhaps through regressing back to a basic state of life, in a 'doomsday prepper' fashion of self-sufficiency, or be resorting to staunch veganism. This does not mean that all and every mode of contemporary food production necessarily break with the creation-based obligations observed by Christians, but the assumption will be that for the average Christian consumers, it is not possible to know whether they observe their religious duties while consuming food, or not. From the above, as seen against the referred wordings of the Declaration and the Covenant, the conclusion to the first question asked here will be that for Christians, food consumption must be considered a manifestation of religious observance that is protected under the Declaration article 18.

\section{Christian observance influencing food production}

As the first question has been answered in the affirmative, the urgency of the second question becomes apparent: How can contemporary animal husbandry and food production be brought into a state where we as consumers are not violating our scripturally given obligations, and this by our mere sustenance-based food consumption in a modern consumerist society? This is of course on the assumption that modern-day modes of animal-based food production is not aligned in all instances with the stewardship obligations under the creation. The aim will be to design mechanisms that promotes the alignment of such production methods in a manner that the Christian consumer may safely procure animal-based food items while still be observing the religious obligations as stipulated in Scripture.

A first obvious avenue to seek when searching for ways to improve food production methods in a religiously acceptable direction, will be through influencing the law giving governments, to force them to change the laws to become in concert with scriptural stipulations and assumptions. As it must be seen as an obligation to the Christian consumers to obey the stewardship obligations when consuming food, and thus their human right to observe and manifest these obligations, it is the responsibility of the state(s) to guarantee that animal husbandry and animal-based food production do not violate against the creation. It should allow for unhindered observance of the adjacent human stewardship obligation. As democratically and societally considerate this may seem, the mere complexity of the task, which will include a myriad of stakeholders and financial interests, will make this a longterm effort at best. Although it should be an aim to create such legislative changes, it may be through voluntary effort that the impact could be most effective - not least in our time with its highly democratised and efficient media access.

One option of influencing food production methods could be to take inspiration from Judaism and Islam, wherein both religious laws concerning permissible food and its production are observed. In Judaism, it is the Old Testament food purity laws which are respected, and the marking of food items with the word 'Kosher' is a way in which the religiously concerned Judaists will know that their food is produced in accordance with their religious beliefs and obligations, including the methods involved in slaughtering the animals (Schechter et al. 1906). Within Islam, it is the term 'Halal' which is in use in connection to sales of permissible food items, and here also the method of slaughtering of certain animals are regulated (Bowker 2009). Also, for the ethically concerned Muslim, there will thus be assistance to find in how the food products are marked and marketed. Without delving into the different factors that motivate the Kosher and Halal paradigms, it will certainly be safe to assume that such systems will influence food production and its methods. Suffice it to say, as in accordance to both mentioned paradigms, the pig is not accepted as fit for human food consumption, and thus the demand for pork will inevitably have to be less than if the opposite was the case. Although not concerned especially with food production, among animal welfare activists, there is a movement promoting merchandise, particularly cosmetics and hygiene products, on the basis that they are not tested on animals (Peta n.d.). These groups also promote the marking 
of acceptable products with a logo: 'not tested on animals'; and from here, some inspiration may be drawn into the context (CCF n.d.).

Within the wider Christian religious paradigm, we have no such established systems for recognising how our food is to be produced on a religiously motivated basis, and thus it is not possible to distinguish food products from each other when measuring them from a Christian-ethical vantage point. It could be a thought to explore whether a food marking system should be established also for Christians, where the focus would be on how the animals involved are treated throughout the production process as measured against our Christian obligations under creation. For this to be viable, it would be necessary to establish a generally accepted norm for how animals are to be treated in order to comply with the relevant Christian-ethical scripturally based norms. Only then would it be possible to promote such values uniformly and in conjunction with a food marking scheme akin to those of Kosher and Halal. If such an agreed paradigm of animal welfare and food production were to be recognised among Christians, then it would as well be easier to envisage that governments would align their law-making activity with Christian norms. This article does not aim to solve this problem - only to invite ideas and further research into the problem spheres which are raised here.

\section{Conclusion}

As appeared in the above, the stewardship obligation under creation as stipulated in Genesis is one that Christians need to observe, and although difficult if not impossible, to uphold in the modern-day consumer society when consuming animalbased food products. As it has been established, the right to practice the Christian belief and manifest it through actions, is protected under the Declaration and the adjacent Covenant, and thus to be able to consume animal-based food without violating scripturally based duties as welcomed by Christians, will then fall under protected human rights. As has been proposed in the above argumentation, for aiding the Christian observance of the stewardship obligations under creation, a general acceptance among Christians on what these obligations entail will be advantageous. If such an acceptance could be translated into a uniform standard for animal welfare alignment in food production, a food marking system could be established for adhering with such standard. This would further the promotion of acceptable treatment of animals as seen from a Christian-ethical perspective. In the article I call for ideas on how such agreement and adjacent food marking system may be achieved.

\section{Acknowledgements Competing interests}

The author declares that he has no financial or personal relationship(s) which may have inappropriately influenced him in writing this article.

\section{References}

Beitz, C.R., 2011, The idea of human rights, Oxford University Press, Oxford.

Bentham, J., 1843, 'Anarchical fallacies: Being an examination of the Declaration of Rights issued during the French Revolution', The works of Jeremy Bentham published under the superintendence of his executor, John Bowring, vol. 2 (Edinburgh: William Tait, 1838-1843), 11 vols. 7/22/2018, viewed 15 September 2018, from http://oll.libertyfund.org/titles/1920.

Bentham, J., 1907, An introduction to the principles of morals and legislation, Library of Economics and Liberty, viewed 15 November 2018, from http://www.econlib.org/ library/Bentham/bnthPML.html.

Bøsterud, M. \& Vorster, J.M., 2017, 'Reoriented investment protocol: A Christianethical perspective on investments', In die Skriflig/In Luce Verbi 51(1). https://doi. org/10.4102/ids.v51i1.2202

Bowker, J., 2009, What Muslims believe, Oneworld Publications, Oxford.

Calvert, S.J., 2008, "'Ours is the food that Eden knew": Themes in the theology and practice of modern Christian vegetarians', in D. Grumett \& R. Muers (eds.), Eating and believing: Interdisciplinary perspectives on vegetarianism and theology, Location 3186-3460, (Kindle), A\&C Black, London.

CCF, n.d., Home page of choose cruelty free, viewed 10 November 2018, from https:// choosecrueltyfree.org.au/

Clapham, A., 2015, Human rights: A very short introduction, Oxford University Press, Oxford.

De Gouge, O., 1791, The declaration of the rights of women, viewed 12 September 2018, from http://chnm.gmu.edu/revolution/d/293/.

Faunalytics, n.d., Homepage of Faunalytics, viewed 11 November 2018, from https:// faunalytics.org/global-animal-slaughter-statistics-and-charts/\#.

Gaggìa, F., Mattarelli, P. \& Biavati, B., 2010, 'Probiotics and prebiotics in animal feeding for safe food production', International Journal of Food Microbiology 141, S15-S28. https://doi.org/10.1016/j.ijfoodmicro.2010.02.031

Geisler, N.L., 2010, Christian ethics, contemporary ethics and options, 2nd edn., Baker Publishing Group, Grand Rapids, MI.

Griffin, J., 2008, On human rights, Oxford University Press, Oxford.

Horrell, D.G., 2008, 'Biblical vegetarianism? A critical and constructive assessment', in D. Grumett \& R. Muers (eds.), Eating and believing: Interdisciplinary perspectives on vegetarianism and theology, Location 1101-1512, (Kindle), A\&C Black, London.

Kearns, L. 1996, 'Saving the creation: Christian environmentalism in the United States', Sociology of Religion, 57(1), 55-70.

Ljungberg, D., Gebresenbet, G. \& Aradom, S., 2007, 'Logistics chain of animal transport and abattoir operations', Biosystems Engineering 96(2), 267-277. https://doi.org/ 10.1016/j.biosystemseng.2006.11.003

Locke, J., 1823, Two treatises of government, Thomas Tegg, London.

Marx, K., 1843, On the Jewish question, viewed 11 October 2018, from https://www. marxists.org/archive/marx/works/1844/jewish-question/.

Mason, J. \& Finelly, M., 2006, 'Brave new farm?', in P. Singer (ed.), In defense of animals: The second wave, pp. 104-122, Blackwell, Malden, MA.

OHCHR, n.d., Official homepage of the UN Office of the High Commissioner for Human Rights, viewed 10 October 2018, from https://www.ohchr.org/en/ professionalinterest/pages/CCPR.aspx.

Peta, n.d., Official homepage for People for Ethical Treatment of Animals, viewed 15 November 2018, from https://www.peta.org/.

Regan, T., 1987, 'The case for animal rights', in Advances in animal welfare science 1986/87, pp. 179-189, Springer, Dordrecht.

Robertson, G., 2012, Crimes against humanity: The struggle for global justice, 4th edn., Penguin, London.

Rousseau, J.J., 1968, The social contract, transl. \& intro. M. Cranston, Penguin, London.

Ryder, R.D., 2006, 'Speciesism in the laboratory', in P. Singer (ed.), In defense of animals: The second wave, pp. 87-103, Blackwell, Malden, MA.

Schechter, S., Greensdtone, J.H.E.G. \& Kohler, K., 1906, 'Dietary laws', in J. Jacobs (ed.), The Jewish encyclopedia, viewed 15 September 2018, from http://www. jewishencyclopedia.com/articles/5191-dietary-laws.

Sentient Media, n.d., Official homepage for Sentient Media, viewed 11 November 2018, from https://sentientmedia.org/about-sentient-media/.

Singer, P., 1995, Animal liberation, Pimlico, London, UK.

United Nations (UN), n.d., The official home page of the United Nations, viewed 15 November 2018, from http://www.un.org/en/index.html.

Vorster, J.M., 2004, Ethical perspectives on human rights, Potchefstroom Theological Publications, Potchefstroom, South Africa.

Waldau, P., 2006, 'Religion and animals', in P. Singer (ed.), In defense of animals: The second wave, pp. 69-83, Blackwell, Malden, MA.

Wirzba, N., 2019, Food and faith: A theology of eating, 2nd edn., Cambridge University Press, Cambridge.

Wise, S.M., 2000, Rattling the cage: Toward legal rights for animals, Profile Books, London, UK.

Wollstonecraft, M., 1792, A vindication of the rights of woman, viewed 20 November 2018, from https://www.marxists.org/reference/archive/wollstonecraft-mary/1792/ vindication-rights-woman/index.htm. 